\title{
Review on Interaction among Boundary Planted Eucalyptus Globules with Soil and Crop
}

\author{
Melkamu Terefe Asmare* \\ Ethiopian Environment and Forest Research Institute, Ethiopia
}

Submission: November 08, 2019; Published: February 03, 2020

*Corresponding author: Melkamu Terefe Asmare, Ethiopian Environment and Forest Research Institute, Jimma Center, Jimma, Ethiopia

Abstract

In recent year single rows of E. globules tree planted along field boards have become a dominant feature of central highlands of Ethiopia. Different journals showed that different extracts of E. globulus leaf had varying degrees of inhibition on germination and seedling growth of $S$. nigrum weed and more inhibition was seen with higher concentrations. In present study, methanol and ethyl acetate extracts had the strongest inhibitory effects. Therefore, it is possible to use these two extracts as a component for production of bio-herbicides. Eucalyptus species caused drawbacks rather than improving the performance of the undergrowth vegetation unlike the mentioned multipurpose trees. Plant secondary metabolites (PSMs) offer plants chemical defences against herbivores and are known to influence intake and diet choice in both insect and mammalian herbivores. That is why eucalyptus leaf palatability to sheep and goat is reduced.

Keywords: Allelopathic; Component interaction; Eucalyptus globulus; Undergrowth vegetation

Abbreviations: Ca: Calcium; CEC: Cation Exchange Capacity; ETB: Ethiopian Birr; ha: Hectare; Mg: Magnesium; K: Potassium; P: Phosphorus;

\section{Introduction}

Eucalyptus is one of the most widely used genera in global commercial plantation timber industries [1]. These plantations are generally nonspecific and have been managed successfully and sustainably for many years. Nevertheless, concerns have been raised about the costs of fertilizers, reduced biodiversity, and productivity losses from pests and disease [2,3]. Mixed-species plantations containing a eucalypt and a nitrogen $\left(\mathrm{N}_{2}\right)$ fixing species have the potential to address some of these concerns and improve nutrient cycling [4], soil fertility [5], biomass production [6,7] and carbon sequestration [8-10] while providing other benefits through a diversification of $[5,11,12]$, improved risk management and protection from pests and diseases $[3,5,13]$.

Mixtures can also be used as a silivcultural system for growing high quality timber [11,13-15]. The design and silviculture of a mixture depends on the specific objectives. For example, the admixed $\mathrm{N}_{2}$-fixing species may be used to produce a wood product or simply to increase $\mathrm{N}$ availability, and the aim of the admixture may be to maximize biomass, volume, or structural diversity, or to improve tree form and wood quality.

\section{Approaches used scope and limitation}

Scope of this term paper includes impacts of Eucalyptus globules on crop, animal, weed, economy and soil properties of different journals. Eucalyptus globules in soil, crop, weed and animal interaction is an iterative process that can be refined through repeated experimentation, monitoring, and readjustments. A single approach by a researcher will not lead immediately to a satisfactory solution for the interaction. The function of the researcher is to provide technical expertise and help the concerned stakeholders in the identification of their problems, the analysis of information, facilitation and monitoring of changes. To this end, a review of different journals approach is employed in this term paper to develop scientifically tested information on their interaction. Research works for greenhouse and field test on chemical characterization allopathic extracts as well as the economic interaction of this tree species is limited.

\section{Summary of the outcome}

Nutrient losses in Eucalyptus globules plantations on soil nutrient status depend on the intensity of biomass removal at harvest. Hydrophobicity can affect soil microorganisms, plant growth, soil hydrology and soil erosion processes at centimeter to catchment scale as confirmed partly by Florenzano (1956) who found that the nitrifying bacteria were very low under the litter of Eucalyptus plantation. Soil under eucalyptus plantation in central highlands of Ethiopia is highly acidic. this is due to leaching of cations deep into the soil since the soil is red and rainfall is high 
$(1560 \mathrm{~mm})$ and due to incorporation of maize stalk that increase humic and fulvic acids in the soil (Dou et al. 2008).

Eucalyptus globules reduce the amount of soil moisture content, organic matter content and base saturation of soil. Soil microorganism is negatively influenced by Eucalyptus. Other than exchangeable calcium and magnesium Eucalyptus globules has low impact on soil potassium content. As Telashwork chane and others said sowing of Maize, Vica faba, barely and Tomato under canopy of eucalyptus have significant impact on yield. Chemicals like methanol and ethyl acetate produced from leaves of eucalyptus retard the of Solinum nigrum weed growth. Study shows that leaf of Eucalyptus globules is unpalatable to goat, sheep and chattels. However, in dry area its shade protects animals from impact of incoming solar radiation.

\section{Types of Interaction}

\section{General description}

Eucalyptus (Myrtaceae family) is native to Australia and has been widely introduced into countries throughout the world, including Saudi Arabia, to produce cellulose, wood for fuel, essential oils or to sequester carbon [16].

Boundary tree plantation is one of the Agroforestry practices which include trees, birds on the tree as hest and crop. This technology is widely practices in northern part of Ethiopia. Eucalyptus globules is the popular tree species planted in the boarder of road and farm. Traditional Agroforestry practices in Ethiopia involve planting tree in various spatial patterns to meet the wood, fuel and fodder requirement of farmers. In recent year, however, single rows of E.globules tree planted along field boards have become a dominant feature of central highlands of landscape.
Tree growing on farm boundaries is a very common practice, but it requires agreement between the neighbours' involved avoiding conflicts. There are different ways of sharing trees planted on a boundary. Sometimes two rows of trees are planted, one on each side of the boundary, and then each farmer grows and manages their own trees. Genotoxicity is defined as variable types of DNA damage and mutations, ranging from gene to structural or numerical chromosome changes. The occurrence of mitotic abnormalities and induction of micronuclei in inter phase cells are main criteria of genotoxic effect. Mitotic activity retardation and disturbances of mitotic phases are reported as indicators of cytotoxic effect (e.g. Delay in seed germination of any species). Several phenolic compounds such as caffeic, coumaric, gallic, hydroxybenzoic, syringic and vanillic acids have been identified as allelochemicals in leaf extracts of Eucalyptus [17].

\section{Soil interaction (soil fertility, chemical, physical, biological)}

Nutrient losses in Eucalyptus globules plantations on soil nutrient status depend on the intensity of biomass removal at harvest. The whole tree harvesting represents an output of $\mathrm{N}, \mathrm{P}$, $\mathrm{K}$, Ca and Mg corresponding to 24.7, 3.6, 25.9, 69.5 and $11.6 \mathrm{~kg}$ ha $^{-1}$ year $^{-1}$, which is not compensated by the natural, inputs (Cortez, 1996). In contrast, the harvest of stem wood only may decrease such depletion to 5.8, 2.0, 10.8, 10.5 and $4.3 \mathrm{~kg} \mathrm{ha}^{-1}$. The proportions of these amounts supplied by annual inputs from the atmosphere were, respectively, $72.6 \%, 6.3 \%, 9.4 \%, 31.1 \%$ and $32.0 \%$. Therefore, the amounts of $\mathrm{N}, \mathrm{P}, \mathrm{K} \mathrm{Ca}$ and $\mathrm{Mg}$, needed to compensate the export through stem wood only removal were, respectively, $1.60,1.89,9.79,7.22$ and $2.93 \mathrm{~kg} \mathrm{ha}^{-1}$ year $^{-1}$. The amounts with respect to $\mathrm{Ca}, \mathrm{K}$ and $\mathrm{Mg}$ may be supplied in high proportion by weathering $[18,19]$ (Table 1 ).

Table 1: The impact of E. globules in soil physical, chemical and biological property.

\begin{tabular}{|c|c|c|c|}
\hline Properties & List of Characters & Amount /Impact & Authors \\
\hline \multirow{4}{*}{ Chemical } & Base saturation & Slow & Madeira [20], Alexander [21] \\
\cline { 2 - 4 } & PH value & Low & Madeira [20], Janice L et al. 2016, Tilashework chane 2009 \\
\cline { 2 - 4 } & $\begin{array}{c}\text { Organic matter as compare with crop } \\
\text { land }\end{array}$ & High & Madeira [20] \\
\cline { 2 - 4 } & $\begin{array}{c}\text { Total Nitrogen content compare with } \\
\text { crop land }\end{array}$ & High & Birru Y et al. 2011 \\
\cline { 2 - 4 } & P>K>Ca>Mg & Fernndo P et al. 2011 \\
\cline { 2 - 4 } & CEC & Low & Alexander [21] \\
\hline \multirow{3}{*}{ Physical } & Soil moisture content & High & Tilashework chane 2009 \\
\cline { 2 - 4 } & Hydrophobicity & increase & Abelho and Graca (1996), Tilashework chane 2009 \\
\cline { 2 - 4 } & Soil degradation & Negatively affect & Alexander [21] \\
\hline Biological & Soil microorganism & Watson (2000) \\
\hline
\end{tabular}

The exchangeable calcium and potassium are all in the high range (llaco,1985). Dedecek et al. (2007) reported that Eucalyptus had a small effect on K level. 


\section{Effect on crop and microclimate}

Table 2: Effects of E. globules on crop and Microclimate.

\begin{tabular}{|c|c|c|}
\hline List of Characters & Amount & Authors \\
\hline Biomass and grain yield from woodlot & $15 \mathrm{~m}$ (Decreased) & EI-Khawas \& Shahata 2005 \\
\hline Plant height of maize & $18.5 \_171 \mathrm{~cm}$ reduced & EI-Khawas \& Shahata 2005 \\
\hline Biomass of maize & $11.8 \_33.3$ ton/ha reduced & EI-Khawas \& Shahata 2005 \\
\hline Grain yield of maize & $4.9 \_13.5$ ton/ha reduced & S.M. El-Darier [22] \\
\hline Coffee shade & Reduce yield & Maissa M et al. [23] \\
\hline Broad bean (Vica faba) \&maize & Reduced yield due to phenolic compound produced & Fikreyesus et al. [24] \\
\hline Barely production & $\begin{array}{c}\text { Reduced due to Water soluble phytotoxic,cytotoxic } \\
\text { and genotoxic chemical produced by eucalyptus }\end{array}$ \\
\hline Tomato & Inhibition increase with increase concentration & \\
\hline
\end{tabular}

Generally, Eucalyptus reduces the crop yield when it is planted near to them.

\section{Effect on weed}

Table 3: Effect of E.globules on weed.

\begin{tabular}{|c|c|c|}
\hline Parts & Effect & Authors \\
\hline Leaves & Unpalatable \& allopathic to pasture growth & Anderson [25] \\
\hline \multirow{2}{*}{$\begin{array}{c}\text { Candidia albicans (infection) concentration in } \\
\text { liver and kidney homogenates rate }\end{array}$} & Reduces /Helps to reduce diabetic infection & Bokaeian et al. [26] \\
\cline { 2 - 3 } & & Alison M [27] \\
\cline { 2 - 3 } & & Alireza Nakhaee et al. [28] \\
\hline
\end{tabular}

\section{Interaction with animal}

Table 4, As stated in the table above eucalyptus improves Candidia infection in normal and diabetic rats that in some ways validates the traditional use of this plant in treatment of diabetic patients. Eucalyptus administration significantly improved the hyperglycemia, polydipsia, polyphagia, and it also compensated weight loss of diabetic rats. Moreover, eucalyptus caused a significant reduction in C. albicans concentration in liver and kidney homogenates.

Table 4: The effect of Eucalyptus globules on Animal.

\begin{tabular}{|c|c|c|}
\hline Parts & Effect & Authors \\
\hline Leaves & $\begin{array}{c}\text { Anpalatable \& allopathic to pasture } \\
\text { growth }\end{array}$ & Bokaeian et al. [26] \\
\hline \multirow{3}{*}{$\begin{array}{c}\text { Candidia albicans (infection) concentration } \\
\text { in liver and kidney homogenates rate }\end{array}$} & $\begin{array}{c}\text { Reduces /Helps to reduce diabetic } \\
\text { infection }\end{array}$ & Alison M [27] \\
\cline { 2 - 3 } & & Alireza Nakhaee et al. [28]; Pass DM et al. [29] \\
\hline
\end{tabular}

\section{Economic interaction (cited by Biruk Ketsela [30])}

Farmers are uses Eucalyptus for feulwood and charcoal production. In tropic and subtropical countries, they plant eucalyptus due to its economic advantages. Compared to other exotic species eucalyptus grow fast and generate income to satisfy their daily expenses. The extra income generated from eucalyptus can contribute to food security. Eucalyptus can start to provide income from age 3-4 in Ethiopian highlands excluding in-between benefits.

Small scale farmers use eucalyptus for fuel wood, fence and construction of houses or to generate income by selling parts or the whole tree (Cefeka, Mager, Weraj, Quwami, and fuel wood). Each of the above activities has different market value including leaves of eucalyptus (Table 5) in different areas. For instance, the price for one sack of leaves (used for baking of Injera) weighing about 25- 30kg is ETB 10-15, one bundle of Cefeka (20- 25 single tree) is ETB 40-45, and Mager (one single tree) is ETB 10-12 in Sendafa town. In Addis Ababa the price for the leaves and the Chefeka is $80-100 \%$ more and for a single tree about $40 \%$ higher. Small scale farmers sell their product at small towns like Sendafa (farmers get somewhat small profit in contrast with the value sold in the big cities). 
Table 5: Market chain for different assortments of eucalyptus in central Ethiopia.

\begin{tabular}{|c|c|c|c|c|c|c|c|c|c|c|c|c|}
\hline \multirow{2}{*}{\multicolumn{2}{|c|}{$\begin{array}{l}\text { Different Assortment of Euca- } \\
\text { lyptus } \\
\text { m }\end{array}$}} & \multirow{3}{*}{$\begin{array}{c}\text { length } \\
\mathrm{cm}\end{array}$} & \multirow{3}{*}{$\begin{array}{c}\text { Diam- } \\
\text { eter } \\
\text { stem }\end{array}$} & \multicolumn{2}{|c|}{ Quantity } & \multicolumn{2}{|c|}{ Years after } & \multirow{2}{*}{\multicolumn{5}{|c|}{ Price different Location/Markets (ETB) }} \\
\hline & & & & \multirow[t]{2}{*}{$\begin{array}{l}\mathrm{kg} / \\
\mathbf{m}^{3}\end{array}$} & \multirow[t]{2}{*}{$\begin{array}{l}\text { Plant- } \\
\text { ing }\end{array}$} & \multirow[t]{2}{*}{$\begin{array}{c}\text { Cop- } \\
\text { picing }\end{array}$} & & & & & & \\
\hline $\begin{array}{l}\text { Amharic } \\
\text { Names }\end{array}$ & & & & & & & & Sendafa & $\begin{array}{l}\text { Addis } \\
\text { Ababa }\end{array}$ & $\begin{array}{l}\text { Debrezey- } \\
\text { it }\end{array}$ & Gimbichu & ELPA \\
\hline Cefeka & $\begin{array}{c}\text { Thin wood used } \\
\text { for between } \\
\text { poles }\end{array}$ & $2+4$ & $\leq 2.8$ & $20-25$ & . & $2 \_3$ & 2 & $40 \_45$ & 80_85 & 50 & 70_75 & . \\
\hline Mager & $\begin{array}{l}\text { used to connect } \\
\text { both construc- } \\
\text { tion poles and } \\
\text { roofs }\end{array}$ & $2+4$ & 45 & 1 & . & $3 \_5$ & 244 & 10_12 & 14_17 & 18 & 10_15 & . \\
\hline $\begin{array}{l}\text { Quami, sere- } \\
\text { gela \& weraji }\end{array}$ & $\begin{array}{c}\text { construction } \\
\text { pole:connect top } \\
\text { of wall \&roof }\end{array}$ & $4 \_8$ & 7.2 & 1 & . & $4 \_8$ & $3 \_6$ & $35 \_40$ & $45 \_50$ & 40 & $20 \_40$ & . \\
\hline $\begin{array}{c}\text { Transmission } \\
\text { pole }\end{array}$ & & $>18$ & 15.4 & 1 & . & $>8$ & $>7$ & $40 \_50$ & 80_100 & 80_85 & . & 72 \\
\hline \multirow[t]{2}{*}{ Gindla } & $\begin{array}{l}\text { tree truck used } \\
\text { for fuel, }\end{array}$ & . & . & . & $1 \mathrm{~m} 3$ & $>12$ & $>10$ & 400 & 430_550 & . & 300_500 & . \\
\hline & $\begin{array}{l}\text { barks,branches } \\
\text { in bundles }\end{array}$ & . & . & . & $25 \_45$ & . & . & 13_16 & . & . & . & . \\
\hline Qitel & leaves in sack & & . & . & 25_30 & . & . & 10_15 & $20 \_25$ & . & . & . \\
\hline
\end{tabular}

Source: Surevy 2011.

Estimation what the farmers and retailers say.

The average benefit per single stem is around 4 ETB and the average benefits per ha per year was about 15,105 ETB. Farmers can get more befits from small wood lots compared to large; the price per stem decrease to about half if a hectare is added to the woodlot (i.e. from the 0.44 ha which is the average of the sample). To increase the rotation with an extra year (beyond the sample average of 7.7 years) will add about $16 \%$ to the benefit obtained per stem. For every 1,000 extra seedlings planted per ha (from the sample average of 10,843 seedlings per ha) the benefit per stem will decrease only with $3.25 \%$ giving a total gain in benefit per ha up to about 20,000 seedlings per ha (if decrease is constant and planting cost is not considered) Table 5 [31-42].

\section{Acknowledgement}

In every beginning we would like to thank the almighty God and Saint Marry. The author acknowledges Doctor Zebene Assfaw for his constructive feedbacks.

\section{References}

1. James R, Del Lungo A (2005) The potential for fast-growing commercial forest plantations to supply high value round wood. Planted Forests and Trees Working Papers, Working Paper 33. Forest Resources Development Service, Forest Resources Division. FAO, Rome, Rome, Italy.

2. DeBell DS, Whitesell CD, Crabb TB (1987) Benefits of EucalyptusAlbizia mixtures vary by site on Hawaii Island. USDA For Serv Res Paper PSW-187.
3. FAO (1992) Mixed and pure forest plantations in the tropics and subtropics. FAO Forestry paper 103 (based on the work of T. J. Wormald). FAO forestry paper 103, Food and Agriculture Organization of the United Nations, F AO of the UN, Rome, Italy.

4. Forrester DI, Bauhus J, Cowie AL (2005b) Nutrient cycling in a mixedspecies plantation of Eucalyptus globulus and Acacia mearnsii. Can J For Res 35: 2942-2950.

5. Montagnini F (2000) Accumulation in above-ground biomass and soil storage of mineral nutrients in pure and mixed plantations in a humid tropical lowland. For Ecol Manage 134: 257-270.

6. Binkley D, Senock R, Bird S, Cole TG (2003b) Twenty years of stand development in pure and mixed stands of Eucalyptus saligna and $\mathrm{N}$-fixing Facaltaria moluccana. For Ecol Manage 182(1/3): 93-102.

7. Forrester DI (2004) Mixed-species plantation of nitrogen-fixing and non-nitrogen-fixing trees. PhD Thesis. The Australian National University, Canberra.

8. Kaye JP, Resh SC, Kaye MW, Chimmer RA (2000) Nutrient and carbon dynamics in are placement series of Eucalyptus and Albizia trees. Ecology 81(12): 3267-3273.

9. Resh SC, Binkley D, Parrotta JA (2002) Greater soil carbon sequestration under nitrogen fixing trees compared with Eucalyptus species. Ecosystems 5: 217-231.

10. Forrester DI, Bauhus J, Cowie AL (2006a) Carbon allocation in a mixedspecies plantation of Eucalyptus globulus and Acacia mearnsii. For Ecol Manage 233(2-3): 275-284.

11. Montagnini F, Gonzáles E, Porras C (1995) Mixed and pure forest plantations in the humid neotropics: a comparison of early growth, pest damage and establishment costs. Commonwealth Forestry Review 74(4): 306-314. 
12. Khanna PK (1997) Comparison of growth and nutrition of young monocultures and mixed stands of Eucalyptus globulus and Acacia mearnsii. For Ecol Manage 94: 105-113.

13. Ewel JJ (1986) Designing agricultural ecosystems for the humid tropics. Annu Rev Ecol Syst 17: 245-271.

14. DeBell DS, Cole TC, Whitesell CD (1997) Growth, development, and yield of pure and mixed stands of Eucalyptus and Albizia. For Sci 43(2): 286-298.

15. Medhurst JL, Pinkard EA, Beadle CL, Worledge D (2003) Growth and stem form responses of plantation-grown Acacia melanoxylon (R. Br.) to form pruning and nurse-crop thinning. For Ecol Manage 179(1/3): 183-193.

16.Zhang C, Fu S (2009) Allelopathic effects of eucalyptus and the establishment of mixed stands of eucalyptus and native species. Forest Ecol Manag 258(7): 1391-1396.

17. Talukdar D (2013) Allelopathic effects of Lantana camara L. on Lathyrus sativus L.: Oxidative imbalance and cytogenetic consequences. Allelopathy J 31(1): 71-90.

18. Cortez NRS (1996) Compartimentos e ciclos de nutrientes em plantações de Eucalyptus globulus Labill. ssp globulus e Pinus pinaster Aiton. Ph.D. thesis. Instituto Superior de Agronomia, Universidade Técnica de Lisboa, Lisboa.

19. Madeira M, Sousa E, Abreu M, Monteiro F, Medina J (1996) Evolução dos constituintes ferruginosos de um substrato arenítico sob influência das raízes de Eucalyptus globulus Labill. Actas do XIII Congresso Latino Americano de Ciência do Solo, 4-8 Agosto 1996, Comissão 2, trabalho 28. São Paulo, Brasil (CD-ROM edition).

20. Madeira M (1989) Changes in soil properties under Eucalyptus plantations in Portugal. In: Pereira JS, Landsberg JJ (Eds.), Biomass Production by Fast-Growing Trees, Kluwer Academic Publishers, Dordrecht, pp. 81-99.

21. Alexander MJ (1989) The long-term effect of Eucalyptus plantations on tin mine spoil and its implication for reclamation. Landscape and Urban Planning 17: 47-60.

22. El-Darier SM (2002) Allelopathic Effects of Eucalyptus Spp on Growth, Nutrient Uptake and Metabolite Accumulation of Vicia faba L. and Zea mays L. Pakistan Journal of Biological Sciences 5(1): 6-11.

23. Morsi MM, Abdelmigid HM (2016) Allelopathic activity of Eucalyptus globulus leaf aqueous extract on Hordeum vulgare growth and cytogenetic behaviour. Australian Journal of crop science AJCS 10(11): 1551-1556.

24. Fikreyesus S, Kebebew Z, Nebiyu A, Zeleke N, Bogale S (2011) Allelopathic Effects of Eucalyptus camaldulensis Dehnh. On germination and growth of tomato. American-Eurasian journal of Agricultural and Environmental Science 11(5): 600-608.

25. Anderson GW (1990) Pine timber and livestock production an agroforestry combination for regions with Mediterranean climate. Agrofore Abst 003-01 159.

26. Bokaeian M, Nakhaee A, Moodi B, Khazaei HA (2010) Eucalyptus globulus (Eucalyptus) Treatment of Candidiasis in Normal and Diabetic Rats. Iranian Biomedical Journal 14(3): 121-126.

27. Gray AM, Flatt PR (1998) Antihyperglycemic Actions of Eucalyptus globulus (Eucalyptus) are Associated with Pancreatic and ExtraPancreatic Effects in Mice. School of Biomedical Sciences, University of Ulster, Coleraine, Northern Ireland, BT52 1SA, UK.

28. Nakhaee A, Bokaeian M, Saravani M, Farhangi A, Akbarzadeh A (2009) Attenuation of oxidative stress in streptozotocin-induced diabetic rats by eucalyptus globules. Indian Journal of Clinical Biochemistry 24(4): 419-425.

29. Pass DM, Foley WJ, Bowden B (1998) Vertebrate herbivory on Eucalyptus - identification of specific feeding deterrents for common ringtail possums (Pseudocheirus peregrinus) by bioassay-guided fractionation of Eucalyptus ovata foliage. J Chem Ecol 24: 1513-1527

30. Biruk Ketsela Hailemicael (2012) The Contribution of Eucalyptus Woodlots to the Livelihoods of Small Scale Farmers in Tropical and Subtropical Countries with Special Reference to the Ethiopian Highlands Swedish University of Agricultural Sciences Faculty of Forest Sciences Department of Forest Products, Uppsala. ISSN 16541367, No 89, 2012.

31. Azizi M, Fuji Y (2006) Allelopathic effect of some medicinal plant substances on seed germination of Amaranthus retroflexus and Portulaca oleraceae. Acta Horticulturea 699: 61-68.

32. Batish DR, Setia N, Singh HP, Kohli RK (2004) Phytotoxicity of lemonscented eucalypt oil and its potential use as a bioherbicide. Crop Protection 23(12): 1209-1214.

33. Batish DR, Singh HP, Setia N, Kohli RK, Kaur S, et al. (2007) Alternative control of little seed canary grass using eucalypt oil. Agronomy for Sustainable Development 27: 171-177.

34. Binkley D, Stape JL, Ryan MG (2004) Thinking about efficiency of resource use in forests. For Ecol Manage 193: 5-16.

35. Del Moral R, Muller CH (1969) Fog drip: a mechanism of toxin transport from Eucalyptus globulus. Bulletin of the Torrey Botanical Club 96(4): 467-475.

36. Kohli RK, Batish DR, Singh HP (1998) Eucalypt oils for the control of Parthenium (Parthenium hysterophorus L.). Crop Protection 17: 119122.

37. Moore P (1997) Effects on biodiversity from Eucalyptus.

38. Paulino VT, Sanchez MJ, Werner JC, Goncalves MA (1987) Allelopathic effect of Eucalyptus on forage growth. Revista De Agricultura Piracicaba 62: 17-35.

39. Ataollahi R, Dejam M, Khaleghi SS (2014) Phytotoxic effects of Eucalyptus globulus LEAF EXTRACT ON Solanum South Western Journal of Horticulture, Biology and Environment 5(1): 43-53.

40. Saberi M, Davari A, Tarnian F, Shahreki M, Shahreki E (2013) Allelopathic effects of Eucalyptus camaldulensis on seed germination and initial growth of four range species. Annals of Biological Research 4(1): 152-159.

41. Setia N, Batish DR, Singh HP, Kohli RK (2007) Phytotoxicity of volatile oil from Eucalyptus citriodora against some weedy species. Journal of Environmental Biology 28(1): 63-66.

42. Singh HP, Batish R, Kaur S, Ramezani H, Kohli RK (2002) Potential utilization of volatile oils from Eucalyptus citriodora Hook for weed management. Journal of Plant Disease and Protection 18: 607-614. 
Your next submission with Juniper Publishers will reach you the below assets

- Quality Editorial service

- Swift Peer Review

- Reprints availability

- E-prints Service

- Manuscript Podcast for convenient understanding

- Global attainment for your research

- Manuscript accessibility in different formats ( Pdf, E-pub, Full Text, Audio)

- Unceasing customer service

Track the below URL for one-step submission https://juniperpublishers.com/online-submission.php 